\title{
Court charges open split in Greek earthquake experts
}

London. Leading Earth scientists in Greece have set up a committee to defend the director of the Greek earthquake planning and protection agency against charges of breach of duty for allegedly disregarding warnings of last June's magnitude 6.1 earthquake which killed 25 people .

Dimitris Papanikolaou has been accused by Athens' public prosecutor, Kolio Kostas, of ignoring two separate warnings of the earthquake. One was issued by Panagyotis Varotsos, professor of solid-state physics at the University of Athens, and the other by Gerasimos Papadopoulos, an associate professor at the Geodynamic Institute of the National Observatory of Athens.

Varotsos used his controversial VAN method, in which an impending earthquake is forecast from a characteristic electrical signal in the ground (see Nature 375, 617; 1995). Papadopoulos's claim was based on the view that an earlier earthquake in northwestern Greece would trigger another rupture within two months. He claims to have been ignored, despite sending in "an accurate prediction" of the time, magnitude and location of the June earthquake, which took place in western Greece.

After a preliminary three-month investigation, the prosecutor has ordered Papanikolaou, who has already had to defend himself once, to testify for a second time. Kostas will then decide if he needs to stand trial on the grounds that heeding the warnings - regardless of their scientific credibility - would have saved lives.

Papanikolaou says he "cannot believe" the decision to charge him, particularly as he is one of a small minority of seismologists in Greece who believe VAN may work. More importantly, he claims to have taken preventive action partly on Varotsos's advice, which turned out to be inaccurate.

"After the May earthquake, I consulted several colleagues, including Varotsos, and decided to alert emergency services in the Thessalia area of central Greece to prepare for a possible earthquake in June," he says. "It is not my fault that the earthquake took place $100 \mathrm{~km}$ south," in the seaside resort of Egion. "This is so ironic, as I am the one accused by colleagues of risking my credibility by helping Varotsos to set up some of his monitoring stations."

The prosecutor's decision has stunned the scientific community. Thirty Earth scientists - including the directors of three major geophysics laboratories - have agreed to testify later this month in Papanikolaou's defence. "This business is a tragedy," says George Stavrakakis, acting director of the Geodynamic Institute of the National Observatory of Athens. "Dimitris
[Papanikolaou] cannot be held responsible when the whole seismological world believes that none of these methods is an acceptable method of earthquake prediction."

Varotsos claims that he has predicted the last three earthquakes in Greece using VAN. But seismologists remain sceptical, pointing out that the technique has not been properly peer-reviewed, and the physics behind the predictions remains unclear.

Both Papanikolaou and Stavrakakis are also angry at the public prosecutor's decision not to take evidence from senior colleagues during the investigation, apart from

\section{IMAGE UNAVAILABLE FOR COPYRIGHT REASONS}

Greek tragedy: would listening to warnings of June's earthquake have saved lives?

Varotsos and Papadopoulos. "If he [the prosecutor] had listened to any one of us, he would have come to a different conclusion," says Stavrakakis.

The prosecutor's decision also puts Varotsos in a tight spot, as Papanikolaou was perhaps his closest supporter among seismologists. But, with both the public and scientific image of VAN at stake, Varotsos has no hesitation in declaring Kostas's decision as "a good initiative".

He says peer review "cannot go on forever" if lives are at risk, just as pharmaceutical companies are allowed to halt trials for AIDS drugs and rush them to market if patients show signs of living longer. "If anyone has doubts about VAN, they need to come out with concrete scientific facts. So far, I have predicted the last three big earthquakes in Greece, which, statistically, is a one-in-seven million chance of happening. This is no fluke, it is based on good science."

Later this month, Varotsos will meet the Greek Prime Minister, Andreas Papandreou, who is believed to have promised more funds for VAN research. The University of California at Berkeley will hold a three-day workshop on the subject on 10-12 October.

\section{Royal Society plans genetics meeting with actuarial profession}

London. Britain's Royal Society is planning to link up with the actuarial profession to explore ways in which mathematicians and epidemiologists can help the insurance industry to assess the health prospects of individuals on the basis of knowledge of their genetic make-up.

In particular, the society is planning a meeting next summer on genetic screening and the insurance industry, to be organized jointly with the Institute of Actuaries. Among other topics, the meeting will discuss "how genetic analysis could be used to identify potential morbidity and mortality in groups and individuals".

The proposed meeting was described last week by Sir Brian Jenkins, master of the Worshipful Company of Information Technologists, at the launch of an initiative known as the City, Science and Technology Dialogue, which is intended to stimulate closer links between Britain's research and investment communities.

In his speech, which was sponsored by the Department of Trade and Industry, Jenkins said that the main purpose of the new initiative was to make city investors more aware of the impact of science, engineering and technology on the health of the economy. Its ultimate aim is "to reinforce the position of the City of London as a knowledgeable capital and securities market for science-based companies here and abroad".

Jenkins described the proposed joint meeting of the Royal Society and the actuarial profession - whose participants, he said, will include researchers from the fields of applied mathematics, epidemiology and demography - as the type of joint research endeavour between scientists and investors that might be promoted under the new initiative.

Officials at the Institute of Actuaries, which is still discussing the detailed programme of the proposed meeting, say that its purpose would be to make actuaries aware of the way in which modern genetic discoveries - many based on the unravelling of the information contained in the human genome - will inevitably affect the way in which health risks are assessed.

Sir Michael Atiyah, the president of the Royal Society, and one of Britain's foremost mathematicians, said that the topic of the use of genetic screening by the insurance industry offered an important opportunity for collaboration between the scientific and financial communities. "Actuaries form a very logical body to partner," he says.

Indeed, Atiyah points out that London's role as both a major international centre for the insurance industry and a focal point for Britain's internationally recognized skills 
in both genetics and mathematics means that it is well placed to play a leading role in linking the two. "The information is all there," he says. "There is no reason why we cannot put it all together."

At the same time, Royal Society officials say that they are well aware of the contentious nature of many of the issues raised by proposals to integrate genetic information into the provision of health and life insurance. They are therefore keen that discussions of the implications of genetic discoveries for the actuarial profession are balanced by consideration of the way in which the use of such information by insurance companies is regulated.

Roy Anderson, Linacre professor of zoology at the University of Oxford, and one of the organizers of the planned meeting, says that its aim will be to explain to the actuarial profession the scientific issues raised by modern genetics, and to provide precise information about "what is and what is not possible".

Anderson says the meeting is likely to address both the practical and ethical issues raised for actuaries, pointing out that the impact of genetics on the insurance industry are likely to be limited on the short-term, but over a longer time scale will become significant. "The Royal Society does not get involved in too many issues at the interface between science and society, but I am convinced that this is one area in which it should be active," he says.

In his speech last week, Jenkins said that the overall purpose of projects such as the genetic screening meeting was "to promote and present scientists and investors as natural partners".

David Dickson

\section{Space station gets pledge of 5-year backing in Congress}

Washington. In a bid to reassure the United States' international partners of its commitment to the space station, the House of Representatives has passed a bill that would authorize $\$ 13$ billion of funding for the project through to its completion in 2002. The multi-year authorization bill, which was sponsored by a bipartisan group led by Bob Walker (Republican, Pennsylvania), the chairman of the House science committee, passed the House on a voice vote last Thursday, with no dissent.

"Our partners overseas keep getting mixed messages," says Dan Goldin, the administrator of the National Aeronautical and Space Administration (NASA). "This will reassure them that America is serious about the space station programme". According to Walker, the House "has taken a giant leap forward in securing the trust of those nations that have entered into cooperative agreements with us."

The passage of the bill indicates the extent to which support for the space station has firmed up in the House of Representatives. In 1993, the project only survived there by a 216-215 margin; but this July, an amendment to kill it fell overwhelmingly, by 287 votes to 132 . Last week, opponents didn't even bother to call for a vote.

But the bill itself is primarily of symbolic importance. To become law, it needs to pass in the Senate. Even if it does, authorization bills merely set funding ceilings; actual budgets are determined by annual appropriations bills.

Walker says that one key Senator - Conrad Burns (Republican, Montana), chairman of the science, technology and space subcommittee - will "aggressively pursue" a similar bill. But Senate staff say the upper house will be reluctant to change its normal practice of passing an annual authorization bill for the whole of NASA.

Supporters believe, however, the bill's passage into law would place a moral obligation on Congress to complete the programme. It has been argued that the Superconducting Super Collider, cancelled by Congress in 1993, would have been more secure from attack if funding had been authorized for completion. Colin Macilwain

\section{Europe edges towards agreement over space funding}

Paris. With two weeks to go before the space ministers of member states of the European Space Agency (ESA) have to take some crucial decisions at a meeting in Toulouse, France, negotiations remain deadlocked about both Europe's contribution to the planned international space station and future funding levels of European space science missions.

But although large obstacles to agreement remain, European space officials say that considerable progress has been made over the past few weeks. In particular, Germany and France seem closer to an agreement about their participation in ESA's planned contribution to the space station.

France has already withdrawn its proposal to substitute a French-built crew rescue vehicle (CRV) for the planned space laboratory, which would be built by Germany and Italy (see Nature 377, 191; 1995). Furthermore, during recent interministerial meetings, France has said it would agree to raise its funding for the station over the period 1996-2000 to around ECU400 million (US\$488 million).
In return, Germany, the ESA member state with the greatest interest in the space station, is said to be ready to invest in the French-led programme to upgrade the Ariane $\mathrm{V}$ launcher, and to agree that ESA's contribution to the station should include money for further technical studies of France's CRV project. Germany has already agreed to pay ECU600 million towards the station programme.

The joker in the pack remains Italy. Earlier this month, the Italian Space Agency (ASI) informally told ESA that it would be unable to pay its expected cash contribution of ECU300 million to the station. Instead, it offered around ECU100 million, with the rest being paid in kind.

This proposition might have ended ESA's hopes of being able to pay for its planned ECU1.4-billion contribution to the station. But the emerging consensus between France and Germany is putting pressure on Italy not to break ranks, and the Italian government is now said to be considering raising ASI's budget in order to allow it to increase its participation.
Meanwhile, at a meeting last week of the ESA council, made up of representatives from each of the agency's member states, Britain refused to budge on its demand that ESA reduce its budget for space science by 25 per cent over five years. But Ian Corbett, the director of science at the UK Particle Physics and Astronomy Council, and the UK's representative on the ESA council, says that "we and ESA recognize that a solution must be found; we live in a real world".

Indeed, in a partial concession to the British demands for reduced funding of the space science programme, ESA has offered to freeze $2.5,5$, and 7.5 per cent of the programme's budget in 1996, 1997 and 1998 respectively. The sum frozen would then be released only after a unanimous vote of the ESA council.

While the United Kingdom is holding out for a better offer, Germany is said to be considering whether to accept this proposal. Both have opposed a proposed increase in the agency's science budget in line with inflation, Germany suggesting it should be kept constant in cash terms. Declan Butler 